\title{
ESTUDIO NARRATIVO SOBRE LA EXPERIENCIA \\ DE LA PATERNIDAD EN PROFESIONALES DE LA EDUCACIÓN
}

\author{
NARRATIVE STUDY ON THE EXPERIENCE \\ OF PATERNITY IN EDUCATION PROFESSIONALS
}

\section{ESTUDAR A NARRATIVA DA EXPERIÊNCIA \\ DE PATERNIDADE PROFISSIONAIS DA EDUCAÇÃO}

\author{
Eduardo Salvador Vila Merino \\ J. Eduardo Sierra Nieto \\ Víctor M. Martín Solbes \\ Universidad de Málaga, España
}

RESUMEN: Con este artículo pretendemos indagar a través de una investigación narrativa en los vínculos entre la paternidad, como experiencia vital, y el ejercicio profesional educativo. En el estudio participaron 24 colaboradores, cuya condición de padres y educadores nos ha permitido una aproximación biográfica a los nexos entre ambas facetas de sus vidas. En él hemos asumido una perspectiva singular y subjetiva de la experiencia de la paternidad, puesta en relación con los procesos de socialización masculina, e imbricados en el desarrollo profesional de cada colaborador. El trabajo realizado supuso para cada caso la recogida y análisis de datos a través de relatos biográficos, con los que buscábamos acercarnos a nuevas formas de encarar la paternidad y su influencia en el propio oficio educativo. En este artículo, aparte de las consideraciones generales derivadas del análisis de los 24 relatos, recuperamos los casos representativos de 4 tipologías desde sus singularidades para tratar de mostrar los sentidos subjetivos de cada colaborador y la comprensión de los escenarios sociales y relacionales en que estas subjetividades se van configurando; tratando con ello de ampliar las concepciones personales, políticas y de justicia social que tiene la profesión educativa, puestas en relación con la identidad de género masculina. Del análisis de los relatos se desprenden conclusiones relacionadas con las potencialidades formativas de lo narrativo, las implicaciones de la paternidad en la vida personal y profesional y sus relaciones, los cambios de mirada que se han producido a partir de ahí y la importancia de reflexionar sobre estas cuestiones desde modelos masculinos alternativos a lo hegemónico. Finalizamos el trabajo apuntando posibles líneas futuras de investigación y actuación a la luz de los relatos. 
PALABRAS CLAVE: Educación social; profesionales de la educación; investigación pedagógica; relación padres-hijos; procesos de interacción educativa; sociedad; educación; perfeccionamiento.

ABSTRACT: With this article we investigate through a narrative inquiry into the links between parenting, and life experience, education and professional practice. The study involved 24 collaborators, whose status as parents and educators has allowed us to biographical approach to the links between the two facets of their lives. In the study we have assumed a unique perspective and opinion of the experience of parenthood, read in conjunction with male socialization processes, and embedded in professional development of each employee. The work resulted in each case the collection and analysis of data through personal accounts, with the approach we were looking for new ways to address parenting and its influence on educational craft itself. In this article, apart from general considerations derived from the analysis of the 24 stories, 4 cases recovered from their singularities to try to show each employee's subjective sense and understanding of social and relational scenarios in which these subjectivities are going setting, thereby trying to expand personal conceptions, political and social justice is the education profession, placed in relation to male gender identity. From the analysis of the stories related conclusions emerge formative potential of narrative, the implications of parenthood in personal and professional life and your relationships, look changes that have occurred from there and the importance of reflecting on these issues from alternative male models to the hegemonic. We finished the job pointing out possible future research and action in the light of the stories.

KEYWORDS: Social education; education professionals; educational research; parent-child relationship; educational interaction processes; society; education; improvement.

RESUMO: Com este artigo, vamos investigar através de uma investigação narrativa sobre as relações entre pais e experiência de vida, educação e prática profissional. O estudo envolveu 24 colaboradores, cujo status como pais e educadores nos permitiu abordagem biográfica para as ligações entre as duas facetas de suas vidas. No estudo, assumimos uma perspectiva única e opinião da experiência da paternidade, em conjugação com os processos de socialização masculina, e incorporado no desenvolvimento profissional de cada colaborador. $O$ trabalho resultou em cada caso, a coleta e análise de dados através de contas pessoais, com a abordagem que estávamos procurando novas maneiras de lidar com pais e sua influência no próprio ofício educacional. Neste artigo, além de considerações gerais derivadas da análise das 24 histórias, 4 casos recuperados de suas singularidades para tentar mostrar sentido subjetivo de cada funcionário e compreensão de cenários sociais e relacionais em que essas subjetividades vão definição, tentando, assim, para ampliar concepções pessoais, justiça política e social é a profissão de educação, colocada em relação à identidade de gênero masculina. A partir da análise das histórias conclusões relacionadas emergem potencial formativo de narrativa, as implicações da paternidade na vida pessoal e profissional e seus relacionamentos, procure mudanças que ocorreram de lá e da importância de refletir sobre estas questões a partir de modelos masculinos alternativos ao hegemônico. Nós terminamos o trabalho apontando possíveis futuras pesquisas e de ação à luz das histórias.

PALAVRAS-CHAVE: Educação Social; profissionais da educação; pesquisa educacional; relação pai-filho; processos de interação educacional; a sociedade; a educação; a melhoria.

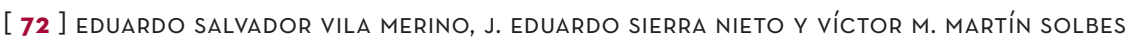

SIPS - PEDAGOGIA SOCIAL. REVISTA INTERUNIVERSITARIA [1139-1723 (2014) 23, 71-94] TERCERA ÉPOCA 


\section{De la masculinidad-paternidad hegemónica a las nuevas masculinidades-paternidades}

La paternidad como experiencia y representación social está actualmente marcada por los cambios sociales y culturales que se han venido produciendo y se proyectan sobre las formas de concebir, expresar y poner en práctica las relaciones en el ámbito familiar como espacio privilegiado para el estudio de los efectos de las concepciones sobre las masculinidades. Son numerosos los estudios que nos hablan de las fatales consecuencias del modelo de masculinidad hegemónico para los hombres, especialmente las más vinculadas con lo cotidiano y lo educativo (Bourdieu, 2000; Connell, 1987; CREA, 2011; Esbrina, 2007; Kimmel, 2000; Mac an Ghaill, 1994; Martino y Pallotta-Chiarolli, 2006; Sancho et. al, 2009; Seidler, 2000), cuestión a la que no son ajenas las relaciones paternofiliales.

Resulta claro que la paternidad goza de su propio régimen de género (Connell, 1997), y que, de forma hegemónica, tradicionalmente, ha estado imbricada en toda una serie de "prácticas de control heteronormativo" (Carrera, 2013, p. 5). Tanto una como otra cuestión han sustraído una serie de percepciones de lo que implica ser y sentirse padre, así como de las conductas 'apropiadas' para ello. Como sucede con otros aspectos de la masculinidad hegemónica, lo emocional se ve subyugado por el estatus de poder. Desde la perspectiva de las nuevas masculinidades (Lomas, 2004; Oliver y Valls, 2004), se intenta plantear la construcción de otra forma de ser hombres (y padres) más sana en lo emocional y lo relacional, contribuyendo a la creación de espacios de convivencia más ricos y diversos donde los hombres nos podamos ver reflejados sin el corsé de los convencionalismos sexistas.

Estas posibilidades, consideramos que pueden visibilizarse de forma prístina en la experiencia de la paternidad, pero para ello hay que poner en cuestión los cánones de la paternidad patriarcal, definida restringidamente como rol socializado en función del sexo donde la posibilidad biológica de ser padre se ve desvinculada de las prácticas de cuidado en el amplio sentido del término. Asimismo, es necesario desvincular la paternidad de formas relacionales dicotómicas basadas en ideologías de poder hacia otras más dialógicas.

\section{From the hegemonic masculinity-paternity to the new masculinities-paternities}

Paternity as experience and social representation is currently masked by social and cultural changes that have been developing and that appear in the ways of conceiving, expressing and putting into practice the relationships in the familiar area as a privileged space for the study of the masculinity conceptions. There are several studies about the fatal consequences of the hegemonic masculine model for men, specially the most linked to the quotidian and educative (Bourdieu, 2000; Connell, 1987; CREA, 2011; Esbrina, 2007; Kimmel, 2000; Mac an Ghaill, 1994; Martino \& PallottaChiarolli, 2006; Sancho et. al, 2009; Seidler, 2000), matter in which the parent-child relationship is not extern.

It is clear that the paternity has its own gender area (Connell, 1997), and, traditionally in a hegemonic way, it has been imbricated in a whole series of 'heteronormativity control practices' (Carrera, 2013, p. 5.) Both matters have made a perceptions' series that involve being and feeling a father, as well as the 'appropriate' behaviors to it. As it happens with other matters related to the hegemonic masculinity, the emotional is subjugated by the power status. From the new masculinities perspective (Lomas, 2004; Oliver \& Valls, 2004), a healthier way regarding to the emotional and relational of being men (and fathers) is trying to be constructed, helping in the creation of richer and diverse spaces where people come together, where men can see themselves without the typical sexist conventionalism.

We consider that these possibilities can be shown in a pristine way in the paternity experience, but for that the patriarchal paternity canons must be called into question, defined as the socialized role depending on the sex where the biological possibility of being father is detached from the care practices in the broad sense of the term. As well, is necessary to detach the paternity from the dichotomous relational forms based in power ideologies to other more dialogical.

From this perspective, the health practices and the emotional education are left aside, with its consequences to men life in general and to the 
Desde esta perspectiva, las prácticas de cuidado y la educación emocional se dejan siempre a un lado, con las consecuencias que conlleva tanto para la vida de los hombres en general como para el ejercicio de la paternidad. Entendemos que los discursos de las nuevas masculinidades también tienen su correlato en lo que se han denominado nuevas paternidades (Bonino, 2003).

Es cierto que ante esa crisis del patriarcado vienen emergiendo experiencias sociales, académicas y también personales de hombres involucrados en procesos de transformación. Esta investigación trata de apoyar la visibilización de historias personales donde se están dando pasos hacia nuevas formas de ser hombre, de ejercer la paternidad y de ser educador (Guash, 2012). La comprensión de las historias singulares puede darnos buena cuenta de algunos de los dilemas a los que nos enfrentamos, así como apuntar posibles líneas sobre las que trabajar.

\section{Padres y además profesionales de la edu- cación: vínculos y relaciones}

Hemos partido de una consideración general de los profesionales de la educación, puesto que la sustantividad de la misma se encuentra en los procesos y las relaciones educativas, independientemente del ámbito profesional en que se desarrollen. Esto no quiere decir que no haya diferencias en la contextualización profesional de dichas prácticas, pero entendemos que igualmente las hay desde el entorno sociocultural de referencia de las mismas y la idiosincrasia personal.

¿Qué sucede cuando uno es padre y además profesional de la educación? ¿Cómo cambia, si lo hace, esta experiencia, la forma en que nos relacionamos educativamente? Estas cuestiones son centrales en nuestra investigación, que parte de ver qué concepciones sobre la paternidad tenemos y cómo las ponemos en práctica, señalando tensiones, pasajes, paradojas. Un ejemplo paradigmático de estas cuestiones podemos verlo desde la relación educativa: ¿qué hace que una relación la consideremos educativa? ¿Es diferente cuando 'ejercemos' como padres que como profesionales de la educación? ¿Qué clase de relaciones entre paternidad y educación pueden parecernos razonables y enriquecedoras? Consi- paternity exercise. We understand that the new masculinities speeches also have its correlate in what has been called new paternities (Bonino, 2003.)

It is true that in front of the patriarchy crisis new social, academic and personal experiences of men involved in transformation processes have been emerging. This research tries to support the awareness of personal stories where new ways of being men, paternity and being an educator are being developed (Gush, 2012.) The understanding of singular ideas may give us the awareness of new problems that we are dealing with, and also new working lines.

\section{Fathers and also education professionals: links and relations}

We have started from a general consideration of the education professionals, as its substantiation is found in the processes and educative relations, independently of the professional field in where they are developed. This does not mean that there are no differences in the professional contextualization of those practices, but we understand that there are in the sociocultural reference environment and in the personal idiosyncrasy.

What happens when a person is a father and also an education professional? How it happens, if it does, this experience, the way in how we are educationally in contact? These matters are essential in our research, it starts seeing what paternity conceptions we have and how we put them into practice, highlighting tensions, passages, paradoxes. We can see a paradigmatic example of these matters in the educative relation: what makes a relation educative? Is it different when we 'work' as fathers than when we work as education professionals? What kind of relations between paternity and education can seem reasonable or enriching to us? We consider that the educative relation is one of the keys in social pedagogy, a relation in which we always move, as fathers and as

[ 74 ] EdUARDO SALVADOR VILA MERINO, J. EDUARDO SIERRA NIETO Y Víctor M. MARTín SOLBES

SIPS - PEDAGOGIA SOCIAL. REVISTA INTERUNIVERSITARIA [1139-1723 (2014) 23, 71-94] TERCERA ÉPOCA 
deramos que la relación educativa es uno de los puntos clave de la pedagogía social, una relación en la cual nos movemos siempre, como padres y como profesionales, en un difícil equilibrio entre la autonomía y el mecanicismo en el quehacer educativo.

Estas dos reflexiones dan la medida de cuestiones sustanciales entre la labor educativa en el contexto paternofilial y profesional. Apostamos por la necesidad de una comunicación entre ambos contextos, que ayude a la mejora de las reflexiones y las prácticas en ambos. Sin embargo, no deja de parecernos fundamental señalar que la implicación emocional y los sentimientos que puede otorgar la experiencia de la paternidad tiene un potencial transformador de prácticamente todos los órdenes de la vida, incluyendo el profesional.

Ocurre que estas dimensiones han sido tradicionalmente vetadas en el imaginario colectivo masculino, donde se da la paradoja de que, a pesar de la ostentación pública de poder asociada a la masculinidad hegemónica, existe una verdadera cortina de humo que no permite que determinados discursos se planteen, como es el caso de las prácticas de cuidado. Por eso la autorreflexión y el autoconocimiento de los hombres sobre sus prácticas, centradas en nuestro caso en la experiencia de la paternidad y la profesional educativa, ha sido escasa, al igual que su interés en el ámbito de la investigación educativa.

La paternidad como realidad, vista desde la sensibilidad y la ternura que da su presencia en hombres que han decidido conscientemente que ésta forme parte de su proyecto de vida, hace que se tambaleen estructuras cognitivas y emocionales. Las prácticas que conlleva, sacan a la luz tanto aspectos positivos como negativos, que se visibilizan más como carencias o falta de corresponsabilidad con la pareja y la descendencia.

\section{Juegos de voces: enfoque narrativo y estu- dios sobre las masculinidades en investiga- ción educativa}

Los seres humanos aprendemos de manera narrativa, dando forma a nuestro conocimiento sobre el mundo, sobre los demás y sobre nosotros mismos en forma de relatos. Como sugieren Bolívar, Domingo professionals, it is a difficult balance between autonomy and the mechanism in the educative task.

These two reflections give the measure of substantial matters between the educative task and in the parent-child relationship and professional context. We bet on a communication necessity between both contexts that helps to the improvement of the reflections and the practices of both. $\mathrm{Ne}$ vertheless, we find essential to highlight that the emotional implications and the feelings that paternity experience may give, have a potential transformer in practically all life orders, including the professional.

These dimensions have been traditionally forbidden in the imaginary masculine collective, where there exist the paradox that there is a real smoke screen that do not allow certain speeches to be outlined, as is the case of health practices, in spite of the public power ostentation linked to the hegemonic masculinity. This is why men self-reflection and self-discovery about their practices, focused in our paternity and professional experience case, have been scarce, as the interest in the educative research field.

Paternity as reality, view from the sensitivity and tenderness that gives its presence in men that have consciously decided this to form part of their life plan, makes the cognitive and emotional structures to be unstable. The practices that it entails, brings to light positive and negative aspects that are shown more as a shortage or lack of joint responsibility with the couple and the descendants.

\section{Voices games: narrative approach and studies about the masculinities in educative research}

Human beings learn in a narrative way, giving shape to our world knowledge, about others and about ourselves in the form of stories. As Bolivar, Domingo and Fernandez (1998, p. 61) suggest it is about an approach that "adopt the metaphor that 
y Fernández (1998, p. 61) se trata de un enfoque que "adopta la metáfora de que las personas son esencialmente escritores de relatos de sus vidas."

Las narrativas aluden tanto a la estructura de la propia experiencia como a las pautas/formas de construir sentido, a partir de hechos temporales personales, por medio de la descripción y análisis de los datos (Bolívar, Domingo y Fernández, 2001). Cuando hablamos de narrativas, aludimos tanto a esa estructuración relatada de la experiencia humana, como al propio enfoque de investigación a través del cual tratamos de construir sentido(s) acerca de lo vivido.

Dentro de lo que conocemos como enfoque biográfico y narrativo, uno de sus principales argumentos guarda relación con la especial consideración de las voces de los participantes. Con esto se trata de quebrar las posturas experimentalistas en la relación sujeto/objeto, reconociendo incluso la presencia del propio investigador en el proceso de construcción deliberativa y dialógica de comprensión. Rivas (2009) ha señalado que bajo el enfoque narrativo difícilmente podemos escindir forma $y$ contenido, ya que nuestros propósitos investigativos y nuestras propias posiciones políticas se ven traducidas en decisiones metodológicas. Hablamos no sólo de una estrategia de recogida de información sino de una forma de concebir la educación y la investigación. Siguiendo con Rivas (2009, p. 20), sostenemos que "la construcción de conocimiento público desde las biografías supone dar valor a las voces propias de los sujetos participantes, como portadoras de sentido y de contenido", lo cual es una reivindicación tanto epistemológica como política. Reconocer la valía y la legitimidad de saberes pedagógicos producidos por los profesionales de la educación, supone una apuesta por romper la jerarquía entre expertos y prácticos (Contreras, 1991), a través de la cual la investigación educativa trata de convertirse en un espacio de comprensión y de transformación social.

Una de las consecuencias del aprendizaje social de las masculinidades hegemónicas tiene que ver precisamente con esta dificultad para conectar con la propia experiencia (Seidler, 2006, p. 127). Dicha conexión es una fuente de sentido personal y profesional, ya que difícilmente podemos escindir quiénes somos de cómo educamos, de ahí que resulte especialmente urgente y relevante aprender a leer people are essentially writers of their life stories."

The narratives refer to the experience structure and to the patterns/ways of building meaning, from temporal personal facts, through description and data analysis (Bolívar, Domingo \& Fernández, 2001). When we talk about narratives, we refer to that human experience structure and to the research approach through which we try to build sense(s) about what they have experienced.

Within what we know as a biographic and narrative approach, one of its main arguments is related with the special consideration of the participant's voices. With this we try to break the experimentalist stances in the subject/object relation, recognizing even the presence of the researcher in the building deliberative and dialogic understanding process. Rivas (2009) has highlighted that under the narrative approach is difficult to divide form and content, as our research purposes and our own political position are translated in methodological decisions. We talk not just about a gathering of information project but also about a way of understanding education and research. Following Rivas (2009, p. 20) we claim that "the public knowledge building from the biographies entails giving value to the participants voices, as carriers of sense and content", which is an epistemological and political vindication. Recognizing the value and legitimacy of pedagogical knowledge produced by education professionals means a bet on breaking the hierarchy between experts and practice (Contreras, 1991) through which the educative research tries to turn into an understanding and social transformation place.

One of the social learning about the hegemonic masculinities consequences is related with this difficulty to connect with experience (Seidler, 2006, p. 127.) That link is a source of personal and professional sense, as it is really urgent and important learning to read between our biographies lines looking for the motivations that support and make sense to those who are educators (Blanco \& Sierra, 2013; Cortés, Caparrós \& Sierra, 2013.) Our gender identity plays a central role in this, who we are, women and men, how we got there and the meaning that we give to this gender iden-

[ 76 ] EDUARDO SALVADOR VILA MERINO, J. EDUARDO SIERRA NIETO Y VÍ́CTOR M. MARTín SOLBES

SIPS - PEDAGOGIA SOCIAL. REVISTA INTERUNIVERSITARIA [1139-1723 (2014) 23, 71-94] TERCERA ÉPOCA 
entre las líneas de nuestras biografías en busca de los móviles que fundamentan y dan sentido a quienes vamos siendo en tanto que educadores (Blanco y Sierra, 2013; Cortés, Caparrós y Sierra, 2013). En todo este entramado juega un papel central nuestra identidad de género, quiénes somos, mujeres y hombres, cómo hemos llegado a serlo, y el sentido que vamos dando a esta identidad de género con el paso de nuestro desarrollo profesional y personal, constituyen un eje sustantivo sobre el que pivotan nuestras concepciones y nuestras prácticas educativas.

Partiendo de estas consideraciones, hacemos notar que de manejarnos exclusivamente en un esquema de relaciones de poder corremos el riesgo de hacer tabla rasa con los sentidos subjetivos que cada hombre construye acerca de sí mismo. Esto tiene que ver con una apuesta decidida por tratar de acercarnos a las vivencias singulares de los hombres, sin perder de vista los marcos que define (con mayor o menos intensidad) la ideología patriarcal, pero sin obviar el reconocimiento de las diversas formas de encarnar las masculinidades, con sus luces y sus sombras (Seidler, 2000, p. 172).

De acuerdo con lo anterior, la narrativa permite articular según qué temáticas, mostrando unos personajes, unos contextos de interacción, unas relaciones; todo ello a través de una trama socio-biográfica que permite comprender tanto las particularidades de la vida de los sujetos, como los contextos socio-históricos en que acontecen.

\section{Diseño de la investigación}

A partir del planteamiento realizado acerca del estudio de las masculinidades, esta investigación ha sido planteada desde un enfoque cualitativo, concretamente desde una orientación narrativa. Específicamente, ante la constatación de la literatura científica, desde la distancia entre la propia experiencia de los hombres y los discursos y saberes emergentes de ella. De ahí que nos propusiéramos diseñar la investigación a partir de una metodología con la que poder aproximarnos a los significados singulares sobre la propia experiencia de la paternidad y sus relaciones (no siempre lineales ni fáciles) con el oficio educativo.

El estudio se desarrolló durante el curso 20122013, contando con la participación de 24 hombres tity with our professional and personal development, which is the central part of our conceptions and educative practices.

Starting from these considerations, we make clear that if we deal exclusively with power relations, we take the risk of making a blank slate with the subjective senses that each men builds about himself. This is related with the decision of trying to get closed to the men singular experiences, without forgetting the frameworks that define (with a higher or lower intensity) the patriarchal paternity, but without avoiding the acknowledgement of the several ways of incarnate the masculinities, with its lights and shadows (Seidler, 2000, p. 172.)

In accordance with the above, the narrative allows articulating depending on the subject, showing characters, interaction's contexts, relations; all these through a socio-biographic plot that allows understanding the subjects' life particularities and the socio-historic contexts.

\section{Research's design}

After the proposal of the masculinities' research, this research has been outlined in a qualitative approach, in particular from a narrative orientation. Specifically, facing the scientific literature verification, from the distance of the men' experience and the speeches and knowledge that emerge from it. That is why we decided to design the research in a methodology that can focus in the singular meanings about the own paternity experience and its relations (not always linear and easy) with the educative task.

The research took place during the year 20122013, with the participation of 24 men between 30 and 55 years old. When we made contact with 


\title{
Ámbitos de indagación \\ Auto-Presentación (personal - profesional)
}

VIDA PRIVADA

Ser hijo

Ser padre

Crianza y relación de pareja

IDENTIDAD MASCULINA

Auto representación Percepciones

Estereotipos

Roles

\section{VIDA PÚBLICA}

La educación Ser educador, ser educadora

Paternidad y docencia

\section{PROYECCIONES}

Deseos

Expectativas

Proyectos de vida

(personal y profesional)

Table 1

\author{
Investigation areas \\ Self-presentation (personal - professional) \\ PRIVATE LIFE \\ Being a son \\ Being a father \\ Raising and couple relationship \\ MASCULINE IDENTITY \\ Self-representation Perceptions \\ Stereotypes \\ Roles \\ PUBLIC LIFE \\ Education \\ Being an educator \\ Paternity and teaching \\ PLANS \\ Whishes \\ Hopes \\ Life project \\ (personal and professional)
}

colaboradores con edades que oscilaban entre los 30 y los 55 años. Al contactar con ellos se tuvieron en cuenta como criterios que se tratase de hombres que fuesen padres y se dedicasen actualmente a la educación, que tuvieran una reconocida sensibilidad hacia las relaciones educativas y con un cierto compromiso con la igualdad de género tanto en su vida pública como privada, sondeando estas cuestiones a través entrevistas exploratorias.

Los objetivos que nos marcamos para el estudio fueron los siguientes:

- Conocer los puntos de vista subjetivos de diferentes hombres dedicados a la educación respecto de su vivencia de la paternidad, sus experiencias como hijos, sus relaciones de pareja o sus posicionamientos educativos.

- Analizar los discursos de estos hombres como padres y educadores desde la perspectiva de la igualdad de género y, específicamente, desde el discurso de las nuevas masculinidades. them the main criteria was that they had to be men that were fathers and that worked in education, were sensitivity to educative relations and some compromise with gender equality in their public and private life, polling this questions through an exploratory interview.

These were our objectives in the research:

- Getting to know the subjective points of view from the different men that worked in education with respect to the paternity experiences, their experiences as sons, their couple relationship or their educative positioning.

- Analyzing the speeches of these men as fathers and educators from the equality of genders' perspective and, specifically, from the new masculinities' speech.

- Creating links between the paternity experience and how it has influenced in the educational professional exercise.

[ 78 ] EDUARdo SALVADOR VILA MERINO, J. EDUARDO SIERRA NIETO Y Víctor M. MARTín SOLBES SIPS - PEDAGOGIA SOCIAL. REVISTA INTERUNIVERSITARIA [1139-1723 (2014) 23, 71-94] TERCERA ÉPOCA 
- Establecer vínculos entre la propia experiencia de la paternidad y cómo ésta ha podido ir influyendo en el ejercicio profesional educativo.

La investigación, partiendo del enfoque narrativo, se concretó en el empleo de relatos autobiográficos que combinaron las estrategias de las entrevistas biográficas y la escritura autorreferencial para los 24 colaboradores.

En la tabla 1 se recogen las dimensiones sustantivas acerca de las cuales les pedimos que articulasen sus relatos. Para los investigadores resultó importante que los colaboradores pudieran dedicarse personalmente a la escritura sin apenas mediaciones, de cara a que dichas narraciones mostrasen precisamente sus puntos de vista respecto al tema de estudio. De este modo, cada uno dio cuenta de sus recorridos vitales haciendo uso de sus propios recursos expresivos y estilo narrativo. Posteriormente, dichas narraciones se fueron completando con un proceso de análisis y contraste con cada colaborador.

El diseño de las guías de escritura respondía a nuestra preocupación como investigadores por conectar la vida personal-privada y la pública, dado que nuestro propósito de fondo ha sido estudiar las relaciones entre la experiencia de la paternidad y la práctica educativa.

La investigación se ha desarrollado en dos fases. En la primera, se realizó el contacto con los colaboradores y se mantuvieron encuentros informales para solicitar su participación y exponer los propósitos del estudio, así como el tipo de implicación que les solicitábamos y las cuestiones éticas de garantías de confidencialidad. Seguidamente, cada uno de los colaboradores produjo su relato personal, tomando como punto de partida la guía de escritura que les facilitamos. Una vez dispusimos de las 24 narraciones, procedimos al análisis singular de cada uno de ellos, produciendo los relatos biográficos. A partir de ahí, los investigadores realizamos el análisis narrativo de los relatos, organizando a partir de las coordenadas diacrónicas y sincrónicas el texto de cada caso. Ese proceso de elaboración narrativa de los casos constituía en sí mismo el análisis y presentación de los hallazgos de esta primera fase. Posteriormente, cada relato fue negociado $y$ consensuado con los colaboradores, buscando man-
The research, starting from the narrative approach, was based in autobiographic stories that combine the strategies of the biographic interviews and the self-referential writing to the 24 contributors.

In table 1 the substantive dimensions in where we asked to create their stories are collected. It was important for the researchers that the contributors could dedicate personally to the writing without intervention, so the stories would show exactly their points of view about the research's subject. In this way, each one told about their vital experiences using their own expressive resources and narrative style. Afterwards, those stories were completed in an analysis and contrasted process with each contributor.

The design of the writing guides answered to our worry as researchers to connect the personal-private life and the public life, as our main proposal has been to study the paternity experience's relations and the educative practice.

The research has been developed in two phases. In the first one, the agreement with the contributors was made and there took place informal meetings to ask for their participation and to talk about the research's proposals, and also the kind of implication that we were asking for and the ethic matters of confidentiality guarantees. Subsequently, each one of the contributors produced a personal story, starting from the writing guide that we gave to them. Once we had the 24 stories, we started with the singular analysis of each one, producing biographic stories. From then on, the researchers made the narrative analysis of the stories, organizing from the diachronic and synchronic coordinates of each text. This narrative elaboration process was itself the analysis and presentation of the findings of the first phase. Lately, each story was negotiated and consensual with the contributors, trying to maintain the ethic criteria of the research and respecting the authenticity and loyalty of the presented information and of the narrative interpretations that we were making.

In the second phase, we made a transversal analysis of the stories. In this phase, we were looking for identifying knots in the masculine experience that connect the links between 
Análisis de datos

RELATOS AUTOBIOGRÁFICOS

(producidos por los colaboradores)

Análisis interpretativo de los relatos:

RELATOS INTERPRETATIVOS

(producidos por los investigadores)
Hincapié en las singularidades de cada colaborador

Recurrencias

\section{Conclusiones}

Table 2

\section{Data analysis \\ AUTOBIOGRAPHIC STORIES \\ (produced by the contributors)}

Interpretative analysis of the:

INTERPRETATIVE STORIES

(produced by the researchers)
Emphasis in the singularities

of each contributor

Recurrences

Conclusions

tener los criterios éticos de toda investigación y, además, respetando la verosimilitud y fidelidad tanto de la información presentada como de las interpretaciones que de las narraciones íbamos realizando.

En la segunda fase, procedimos a un análisis transversal de los relatos. Lo que buscamos en esta fase fue identificar nudos en la experiencia masculina que engarzan los vínculos entre paternidad y práctica profesional. Consideramos que los relatos permiten señalar dichos nudos o ejes, aportando información acerca de cómo son vividos por diferentes hombres, de modo que nos ayuden a seguir indagando y a proponer acciones formativas para trabajar sobre ellos.

Lo que presentamos en este artículo, es tanto un extracto de los relatos biográficos que compusimos (a través de casos representativos de 4 tipologías seleccionados por sus propias singularidades y significatividad) como una muestra, a partir de dichos relatos seleccionados, de los principales hallazgos que se derivaron del análisis cruzado de los mismos.

Como pudimos ir comprobando, la experiencia de la paternidad se engarza con fuerza en la histo- paternity and the professional practice. We consider that the stories let highlighting those knots, providing information on how they are lived by different men, in a way that help us to continue researching and to suggest formative actions to work on them.

What we present in this article it is an extract of the biographic stories that we created (through representatives cases of four typologies selected regarding to their own singularities and significance) as a sample, from those stories selected, of the main findings that emerged from the crossover analysis.

As we could check, the paternity experience is linked to the contributors' life story, not just in being parents, it is also linked to the biographic process, of vital decisions, of life projects' elaboration. We can advance that the phenomenological experiences of paternity and the senses constructed in relation to it are defined before, during and after the beginning. The stories show a series of relations, experiences, subjective experiences, socio-historic contexts, where the pater-

[ 80 ] EDUARDO SALVADOR VILA MERINO, J. EDUARDO SIERRA NIETO Y VÍCTOR M. MARTíN SOLBES SIPS - PEDAGOGIA SOCIAL. REVISTA INTERUNIVERSITARIA [1139-1723 (2014) 23, 71-94] TERCERA ÉPOCA 
ria de vida de los colaboradores, no reduciéndose exclusivamente al hecho en sí de ser padres, sino que va ligado al proceso biográfico, de decisiones vitales, de conformación de proyectos de vida. Podemos avanzar que la vivencia fenomenológica de la paternidad y los sentidos construidos en relación a ella se conforman antes, durante y después del nacimiento. Los relatos ofrecen un entramado de relaciones, vivencias, percepciones subjetivas, contextos socio-históricos, donde se van "ejerciendo y conformando" las paternidades y su vínculo con el ejercicio profesional educativo.

El proceso de análisis de los relatos descrito podemos visualizarlo a través de la tabla 2.

\section{Caso 1. "La defensa de los derechos de mi hijo me hizo consciente de la dimensión social, política y de justicia que tiene la profesión educativa"}

El primer colaborador tiene 50 años. Está separado, tiene un hijo y su profesión es la enseñanza. Afirma que si tuviera que decir quién es, respondería que no lo sabe. Se define como alguien paciente y que sabe escuchar. Ama profundamente a su hijo y la literatura.

Ha pasado de ser hijo a ser padre, lo que constituye transformaciones vitales, cambios en los modos de vida, en la organización de la casa, del tiempo, de las relaciones familiares, de las relaciones con la pareja. Considera que la responsabilidad se incrementa dado que "ya no comparto la vida con un adulto, que puede valerse por sí mismo, sino que tengo que cuidar de una persona indefensa y educarla para que sea autónoma".

Con la experiencia de la paternidad ha descubierto que es capaz de desplegar una energía que, hasta ese momento, no sabía que poseía.

Afirma que hay un antes y un después en su vida debido al nacimiento de su hijo, así como también lo hay en su labor como educador. A la educación llegó por diversas circunstancias, no por vocación; aunque dice sentir desde siempre un gran respeto por su profesión e intenta llevarla a cabo de la manera más honesta posible, formándome continuamente para mejorar y ponerse al servicio del alumnado con el que trabaja.

Cuando nació su hijo, se sentía en crisis y decepcionado profesionalmente, debido a las dificul- nities and its link with the educative professional exercise are "practiced and defined."

We can see he stories analysis process described through the table 2 .

\section{Case 1. "The defense of my son's rights made me aware of the social, politic and justice dimension that the educational profession has"}

The first contributor is 50 years old. He is separated, he has a son and he work as a teacher. He claims that if he had to say who he is, we would answer that he does not know. He defines himself as a patient person and a great listener. He loves deeply his son and literature. He has changed from being a son to being a father, which builds vital transformations, changes the way of life, the house's organization, the time, the familiar relationships, the couple relationship. He considers that the responsibility increases due to "I do not share anymore my life with an adult that can fend for himself, I have to look for a defenseless person and educate that person to be self-sufficient."

With the paternity experience he has found out that he is able to display an energy that, up to now, he did not know that he had.

He claims that there is a before and an after in his life due to his son's birth, as well as in his work as educator. He started working in education due to several circumstances but not for vocation; although he says that he has always felt a deep respect for his profession and he tries to perform it in the most honest way, constantly training himself to improve and work with his students.

When his son was born, he felt in crisis and professionally disappointed due to the difficulties that he found in the daily job of the profession, despite of having found its beauty. Nevertheless, there 
tades que encontraba en el quehacer diario de la profesión, a pesar de haber descubierto su hermosura. Sin embargo, eran muchas las ilusiones e inocencias que se estrellaban contra un muro con el paso del tiempo.

En estas circunstancias nació, su hijo y no vino solo, afirma que vino con síndrome de Down. Pasado el primer shock y una vez siendo consciente del cambio que se estaba produciendo en sus vida, él y su pareja deciden buscar asesoramiento y ayuda; "con el transcurrir del tiempo, y gracias a la convivencia con nuestro hijo, descubrimos que todos somos diversos y merecemos ser educados en la diversidad cooperativamente". A partir de estos momentos y "gracias a mi hijo, me reencontré con la profesión educadora". Al principio tuvo que formarse y todo lo que aprendió para educar a su hijo le sirvió para educar a su alumnado. "La defensa de los derechos de mi hijo, me hizo consciente de la dimensión social, política y de justicia que tiene la profesión educativa". Afirma que, a través de su hijo, ha aprendido el sentido de la paciencia, los ritmos individuales de aprendizaje, la necesidad de reconocer las peculiaridades, las individualidades, evitando la estigmatización y el etiquetado, tan frecuente en algunos entornos, llamados educativos, que en realidad son segregadores.

En definitiva, "gracias a mi hijo me he acercado al alumnado estableciendo unas relaciones educador/alumno muy fructíferas".

\section{Caso 2. "Trato de ser padre, siendo, compartiendo, aprendiendo de mi hija y con ella"}

El segundo hombre tiene 30 años; está casado, con una hija y a punto de ser de nuevo padre. Trabaja en educación como terapeuta y especialista en autismo por lo que, afirma, su trabajo le "mantiene en contacto con una dura realidad a la vez que vital".

Los primeros recuerdos de su niñez, sobre todo, están vinculados a la relación que tuvo con su madre, ya que su padre tenía dos trabajos y llegaba tarde a casa y apenas coincidían más allá de los fines de semana. Cuando tenía 7 años, su padre dejó uno de sus trabajos y comenzaron a tener más contacto, prácticamente inició su relación con él. “Me llevaba a las actividades extraescolares y como él era deportista, me apuntó a baloncesto; hecho éste were a lot of hopes and innocence that hit with a wall over time.

Within these circumstances his son was born and he did not arrive alone, he had Down syndrome. When the first shock passed and once he was aware of the change that his life was suffering, him and his couple decided to look for advice and help; "over time, and thanks to living with our son, we found out that we are all diverse and we deserve to be educated in diversity cooperatively." In this moments and "thanks to my son, I reencountered myself with the educative profession." At first he had to train himself and all he learned to educate his son was useful to educate his students. "The defense of my son's rights made me aware of the social, politic and justice dimension that the educational profession has." He claims that through his son he has learnt the sense of patience, the individual learning rhythms, the necessity of recognizing peculiarities, individualities, avoiding stigmatization and labeled, so frequent in some environments, called educative that are actually segregated.

In conclusion, "thanks to my son I have come close to my students creating a very productive educator/student relations."

\section{Case 2. "I try to be a father, being, sharing, le- arning with my daughter and from her"}

The second one is 30 years old; he is married, with a daughter and about to being father again. He works in education as therapist and autism specialist that is why his work "keeps him in contact with a harsh but vital reality."

His first childhood memories are, above all, linked to the relationship with his mother, as his father had two jobs and arrived every day late at home and they hardly happened to meet but the weekends. When he was 7 , his father left one of his jobs and they started to have more contact, practically he started his relationship with him. "He took me to extracurricular activities and as he was athletic, he signed me up for basketball; fact that

[ 82 ] EDUARDO SALVADOR VILA MERINO, J. EDUARDO SIERRA NIETO Y VÍ́CTOR M. MARTíN SOLBES SIPS - PEDAGOGIA SOCIAL. REVISTA INTERUNIVERSITARIA [1139-1723 (2014) 23, 71-94] TERCERA ÉPOCA 
que me ha marcado la vida, ya que practicando este deporte conocí qué era el esfuerzo, aprendí a formar parte de un grupo, a tomar decisiones, a respetar, a ganar y a saber perder; mi padre me llevaba a los entrenamientos y a los partidos y se desvivía para que fuera cada vez mejor jugador; creía en mi". Poco a poco, esta actividad lúdica adquirió un matiz de presión, ya que cada vez le exigía más y, a veces, tiene la sensación de que le torturaba cuando hacía un mal partido. Él se revelaba y siempre acababan discutiendo; por el contrario, cuando hacía un buen partido, todo eran elogios y valoraciones positivas. Tras pasar varios años jugando a baloncesto en varios equipos y acercarse el momento de entrar en la universidad, le dijo a su padre que estaba cansado y que ya no quería seguir jugando, lo que constituyó momentos frustrantes y de cierta amargura para ambos, "pero al final estaba mi decisión aunque no era compartida por mi padre que todavía recuerda aquellos momentos de manera vital". Ingresó en la universidad y a los tres meses abandonó los estudios de Empresariales hasta el siguiente año, en el que comenzó estudios relacionados con la educación. "Mi padre no entendía nada, pero asumió que era libre para elegir".

Aprendió de su padre la importancia de tratar de ser felices, sentirse seguro de sí mismo e intentar buscar el lugar adecuado en la sociedad. Dice identificarse con él por la inestabilidad vital, por los diferentes estados de ánimo por los que pasa. Sin embargo, desde que es padre no se identifica con el suyo en el estilo de crianza: "tomo decisiones junto a mi pareja respecto a nuestra hija sin importarme demasiado otras opiniones".

En cuanto a su experiencia como padre, afirma que su vida ha cambiado radicalmente con la paternidad: "mis preocupaciones han pasado de ser por mí mismo y por mi pareja, a ser preocupaciones por lo que pueda afectar a nuestra hija; se ha reducido mi ansiedad personal para, de algún modo, ser convertida en responsabilidad familiar". "Trato de ser padre, siendo, compartiendo, aprendiendo de mi hija y con ella; experimento, acierto, me equivoco, pero sobre todo, uso el sentido común, respetando su desarrollo vital".

Está convencido que mantienen una relación excepcional, inolvidable, gratificante, aunque está convencido que su relación es totalmente diferente a la has marked my life because practicing this sport it is how I knew what making an effort was, I learned being part of a team, making decisions, to respect, to win and how to lose; my father took me to practice and to the matches and he worked very hard to make me a good player; he believed in me." Little by little, that playful activity took a pressure nuance, as each time he was required more and, sometimes, he has the feeling that he tortured him when he made a bad game. He revealed himself and they always argued; on the other hand, when he made a good game, everything was praises and all the comments were positive. After several years playing basketball in different teams and reaching the moment to get into college, he told his father that he was tired and that he did not want to continue playing anymore, which created frustrating and bitterness moments for both of them, "but finally was my decision besides my father did not share it, he still remember those moments in a vital way." He joined university and three months later he gave up Business studies, the following year he started studies related to education. "My father did not understand anything, but he accepted that I was free to choose."

He learned from his father the importance of trying to be happy, feeling self-confident and trying to look for his place in society. He says that he identifies himself with him due to his vital instability, to the different moods he feels. Nevertheless, since he is father he does not identify himself with his father's raising way: "I make the decisions with my couple in what regards to my daughter, without caring of other opinions."

Regarding to his experience as father, he claims that his life has radically changed with paternity: "my worries have passed from being about myself and about my couple to be worries about what could affect our daughter; my personal anxiety has been reduced to turn into familiar responsibility." "I try to be a father, being, sharing, learning with my daughter and from her; I experiment, get right, get wrong, but above all, I use my common sense, respecting the vital development."

He believes that they have an exceptional relationship, unforgettable, gratifying, besides he believes that his relationship is totally different from the relationship that his daughter has with her mot- 
que mantiene su hija con la madre. Cree que toda la crianza debe ser natural y que no hay que forzar ninguna situación, ahora toca disfrutar de su hija, compartiendo el tiempo con ella.

Su trabajo como terapeuta le aporta mucha tranquilidad a su vida ya que habla, escucha, muestra posibilidades y los padres de los niños y niñas con los que trabaja toman las decisiones. Considera importante trabajar con personas e intentar responder a cuestiones como: ¿te sirve para algo?, ¿te hace bien? Sin entrar en más valoraciones ni tomar decisiones por nadie, cada uno es responsable.

No cree que existan diferencias importantes entre los hombres y mujeres que se dedican a la educación, ya que opina que "los que nos dedicamos a esto, tenemos una especial sensibilidad". "Ser maternal es lo mismo que ser paternal aunque este sentimiento se viva de manera diferente". Afirma que no por ser hombre se tiene más autoridad que por ser mujer, pero, por la misma razón, tampoco tiene menos sensibilidad, porque considera que: "una relación es educativa cuando crea conflicto, cuando hace pensar". Partiendo de estos planteamientos, sus relaciones educativas han evolucionado debido a su paternidad: "he adquirido un sentimiento que me hace entender lo que siente un padre, una madre, un hijo, una hija, procuro estar más atento a este sentimiento". También ha cambiado la manera en la que mira a los padres, aunque reconoce que en el ámbito laboral no aflora su sentimiento de paternidad.

Como educador intenta transmitir seguridad en lo que hace, sensibilidad respecto a la persona con la que está: "como hombre educador exactamente lo mismo".

Respecto al futuro, mantiene que, como padre y educador, quiere seguir siendo, cuestionando, repensando. En el trabajo con los chicos autistas, su propuesta metodológica va directamente al acierto porque en las primeras etapas, esto les añade confianza y fuerza para seguir actuando; por el contrario, en su paternidad, siempre propone la indagación como método educativo.

\section{Caso 3. "Me une al alumnado un especial instinto tutorial"}

El tercer colaborador es un hombre de 52 años, procedente de una familia numerosa, padre de una hija her. He believes that every raising must be natural and no situation has to be forced, now is the moment to enjoy his daughter, sharing time with her.

His work as therapist gives a lot of calm to his life as he talks, listens, shows possibilities and the children's fathers are the ones who make the decisions. He considers important working with people and trying to answer questions as: is it worth for you? is it good for you? Without saying anymore or taking others decisions, each one is responsible of himself.

He does not believe that there exist huge differences between the men and women that work in education, he thinks that "the ones who dedicate to this, have a special sensitivity." "Being maternal is the same as being paternal although this feeling is lived in a different way." He claims that not for being a man there is more authority than for being a woman, but, for the same reason, there is not less sensitivity, he considers that: "a relationship is educative when it creates conflict, when it makes thinking." Starting from these proposals, his educative relationships have evolved due to his paternity: "I got a feeling that makes me understand what a father, a mother, a son, a daughter feels, I try to be more attentive to this feeling." He has also changed the way in how he looks to parents, besides he recognizes that in the working area he does not show his paternal feeling.

As educator he tries to communicate certainty in what he does, sensitivity with the person: "as an educator man exactly the same."

Regarding to future, he claims that, as father an educator, he wants to continue being, questioning, rethinking. In his work with autistic boys, his methodological offer goes straightly to the right because in the first phases this gives them confidence and strength to continue acting; on the other hand, in his paternity, he always proposes investigation as educational method.

\section{Case 3. "I am closed to the students thanks to a special tutorial instinct"}

The third contributor is 52 years old, coming from a large family and father of a daughter. He has al-

[ 84 ] EDUARDO SALVADOR VILA MERINO, J. EDUARDO SIERRA NIETO Y VÍCTOR M. MARTíN SOLBES

SIPS - PEDAGOGIA SOCIAL. REVISTA INTERUNIVERSITARIA [1139-1723 (2014) 23, 71-94] TERCERA ÉPOCA 
a la que siempre inculcó el valor de la autonomía y de la responsabilidad. Trabaja en el ámbito educativo, actualmente como orientador de un centro educativo. Su infancia vino marcada por la experiencia de la emigración y temprana muerte de su padre debido a la continua ingesta de alcohol. Fue educado, él dice adoctrinado, en el marco de una tradición religiosa castrante. "Crecí en un domicilio muy humilde de un barrio humilde y en un colegio con enseñanza segregada, que se cumplimentaba con charlas parroquiales que, a pesar de ser bienintencionadas, amenazaron mi juventud".

Su primera experiencia escolar "fue frustrante" ya que suspendió el acceso al bachillerato, lo que le marcaba claramente un destino hacia el ámbito laboral o al de la formación profesional. Posteriormente, se benefició del giro que sufrió el sistema educativo, que le permitió acceder al bachillerato y posteriormente a la universidad. Ha trabajado como profesor de matemáticas, asesor de formación, ha sido miembro del Gabinete de Asesoramiento para la Convivencia Escolar y en la actualidad es orientador escolar.

Considera que los problemas de convivencia en la comunidad educativa vienen marcados "por las relaciones de dominio-sumisión estereotipadamente masculinas". Se cuestiona sobre la hipotética posibilidad de que hombres y mujeres sean educados y educadas desde sus nacimientos, en el desarrollo de cualquiera de sus rasgos, independiente de su sexo de partida. Afirma que esa manera de desarrollarse debe comenzar por uno mismo en las vivencias personales, y él ha sido afortunado porque junto a su pareja han experimentado "esta realización personal a partir de un planteamiento de durabilidad mientras se sientan vinculados por afectos $y$ se sientan libres".

Respecto a su hija, por el ahínco que han puesto, tanto su compañera como él, en las cuestiones género e independencia económica, se hubieran sentido frustrados si su hija hubiera optado por un modelo de vida dependiente o en compañía de una pareja que le hubiera hecho vivir episodios violentos.

Se considera una persona sensible, por lo que, a veces, "reprimía esos sentimientos de sensibilidad". "Valoro considerablemente la pedagogía del cuidado, la importancia del afecto, la sensibilidad, la empatía, la corresponsabilidad doméstica". ways taught her the autonomy and responsibility values. He works in education, currently as a school counselor in an educational establishment. His childhood was marked by the emigration experience and the early death of his father due to the continuous alcohol intake. He was educated, he says indoctrinated, in the framework of religious tradition. "I grow up in a humble home in a humble neighborhood and in a school with a segregated education, that was completed with parish speeches that in spite of being well-meaning, they threatened my youth."

His first scholar experience "was frustrating" as he failed the access to high school which meant a destiny to the labor area or to vocational training. Lately, he benefited from the change in the educative system that let him enter in high school and later in university. He has worked as mathematics teacher, training adviser, he has been member of the Office of Scholar Cohabitation Advising and currently he is a scholar counselor.

$\mathrm{He}$ considers that the cohabitation problems in the educational community are marked by "the stereotyped masculine control-submission relations." He has asked himself about the hypothetic possibility that men and women are educated since they were born, in the development of any of their features, independently of their sex. He claims that this way of developing must start by oneself in our own personal experiences, he has been lucky because with his couple they have experimented "this personal realization from a durability approach while they are liked by fondness and they feel free."

Regarding to my daughter, due to the efforts that his partnership and him has made in gender matters and in economic independence, they would have felt frustrated if their daughter had chosen a dependent way of life or next to a couple that made her live violent episodes.

He considers himself as a sensitive person that is why, sometimes, "I contained those sensitivity feelings." "I appreciate the care pedagogy, the importance of fondness, sensitivity, empathy, domestic joint responsibility."

$\mathrm{He}$ is vocationally educator, teacher; "I am closed to the students thanks to a special tutorial instinct, there is a feeling that makes impossible to 
Se siente vocacionalmente educador, maestro; "me une al alumnado un especial instinto tutorial, del que se desprende un sentimiento que imposibilita separar mi yo personal de mi yo profesional, a través de relaciones genuinas, coherentes y transparentes que desembocan en un modelo coeducativo de autoridad que integra disciplina y afecto".

\section{Caso 4. "Miro a las personas, al alumnado, de ma- nera más honda y con más dimensiones"}

El cuarto colaborador es un hombre de 39 años, casado y con dos hijos, una niña y un niño, vinculado profesionalmente a tareas educativas con familias que sufren las consecuencias de la exclusión social, además de ejercer docencia en la universidad.

Cree poseer facilidad para acercarse a las personas y escucharlas y se siente muy preocupado por la pobreza y precariedad que a diario percibe a su alrededor.

Su padre falleció joven, a los sesenta años; recuerda de él que "era una persona con ansias de vida y libertad, muy trabajadora y responsable". Recuerda de su niñez la capacidad que tenía su padre para dialogar con él y con sus hermanas. Aprendió de él que "el ser humano tiene que ser digno y esforzarse por lo que quiere, y esto no va reñido con el disfrute de las pequeñas cosas". Dicen sus amigos y familiares que se parece a su padre y esto le llena de orgullo, aunque él procura no preocuparse demasiado por las cosas que no puede abordar, al contrario que su padre, que vivía en un continuo estrés y cansancio debido a estas preocupaciones.

Respecto a sus hijos, cree que "hay un antes y un después de sus nacimientos, sentimientos encontrados y expectativas con la primera, e intensidad y serenidad con el segundo". Su vida ha cambiado en las relaciones con amigos, pareja, familia, responsabilidades, etc. Intenta que el tiempo que comparte con sus hijos sea de calidad, tratando que perciban que "siempre estaré acompañándolos, pero que las decisiones serán de su responsabilidad". Tiene la sensación que no está con sus hijos suficiente tiempo y lo que es paradójico, tampoco tiene tiempo para él mismo; algunas actitudes y comportamientos de sus hijos lo frustran y lo cansan existencialmente, en todo momento. Considera que "mis hijos son distintos por ser personas distintas, no por su género". Toma to- separate personal me from my professional me, through genuine, coherent and transparent relationships that result in a coeducational model of authority that integrates discipline and affect."

\section{Case 4. "I look to people, to students in a deeper way and with more dimensions"}

The fourth contributor is a 39 years old men, married and with two children, a boy and a girl, professionally linked to educative tasks with families that suffer the social exclusion consequences, he also works as a lecturer in university.

He thinks he has an ability to come close to people and to listen to them and he is very worried about the poverty and the scarcity that he daily sees around him.

His father died young, when he was sixty years; he remembers from him that "he was a person that wanted to live and be free, hard-working and responsible." He remembers from his childhood the capacity of his father to talk with him and his sisters. He learned from him that "the human being has to be worthy and make an effort to obtain what he wants, this does not go against enjoying the little things." His friends and family say that he resembles to his father and this makes him very proud, although he does not care very much for the things he cannot address, in contrast to his father who lived in continuous stress and fatigue due to these concerns.

Regarding to his children, he believes that "there is a before and an after their births, mixed feelings and hopes with the first one and intensity and calm with the second one." His life has changed in the relationship with friends, couple, family, responsibilities, etc. He tries that the time he spend with his children is of high quality, trying that they feel that "I would always be with them bur their decisions are their responsibility." He feels that he does not spend enough time with his children and what is paradoxical, he does not have time to himself; some of his children' attitudes and behaviors are disappointing and they existentially tired him. He considers that "my children are different because they are different people, not due to their gender." He makes all the decisions related to

[ 86 ] EDUARDO SALVADOR VILA MERINO, J. EDUARDO SIERRA NIETO Y VíCTOR M. MARTíN SOLBES 
das las decisiones relacionadas con sus hijos consensuadas con su pareja y procuran que las obligaciones paternas y maternas dejen un espacio para cada uno de ellos, para su relax.

Tiene un alto concepto de su profesión y enfatiza el respeto que merecen las personas con las que trabaja. Cuenta cómo ha evolucionado en su percepción sobre lo educativo, "sobre todo, en mi capacidad para analizar los entornos donde trabajo y la manera de dirigirme a las personas con las que trabajo y decirles lo que pienso en cada momento".

No cree que existan diferencias en ser hombre o mujer, a la hora de educar, "si las hay es porque cada uno es diferente, no por cuestiones de género". Creo que lo maternal va unido a "valores de cercanía, afecto, seguridad, cariño, por lo que no creo que lo maternal sea exclusivo de la mujer".

En lo profesional, considera indispensable " $v i$ sualizar la actividad educativa con sensibilidad ética". Su experiencia paternal, cree que ha cambiado su manera de ejercer la profesión educadora, "miro a las personas, al alumnado, de manera más honda y con más dimensiones".

Cree que un hombre es un ser dotado de capacidad de pensar, con necesidad de relacionarse para construir su vida, por lo que discrepa del concepto de hombre imperante en nuestra sociedad, que lleva consigo algunos valores estigmatizadores. No sabe qué es un 'hombre educador', "pero si alguien se dedica a la educación, debe tener claro quién es, lo que espera de la vida, cómo quiere relacionarse, etc.".

En cuanto al futuro, cree que lo más importante para sus hijos es que perciban que sus padres los quieren. Tanto para ser mejor padre como mejor profesional, estima que es necesario continuar "aprendiendo a respetar los procesos personales y cuidar de su vidas". Y para acompañar la educación, tanto de sus hijos como de los educandos, "creo necesario establecer espacios en común, donde dialogar, aprovechar el potencial educativo del día a día, ser conscientes de que los protagonistas son ellos y que las respuestas a sus preguntas las tienen ellos".

\section{Conclusiones}

El vínculo entre la paternidad como experiencia vital y el ejercicio profesional educativo en el marco de la construcción de nuevas maneras, más igualitarias, their children in agreement with his couple and they try that the paternal and maternal duties leave them space for each one of them, to their relax.

He has a high concept of his profession and he emphasizes the respect deserved to the people he works with. He tells how his perception about educative has evolved, "above all, in my capacity to analyze the environments where I work and the way to talk to the people whom I work and tell them what I think in each moment."

He does not believe that there are differences between being men or women while educating, "if there are differences is because each one is different, not due to gender matters." I believe that the maternal is linked to "proximity, fondness, certainty, affection principles, so I do not think that maternal is women exclusively."

In the professional area he considers essential "to visualize the educational activity with ethic sensitivity." He believes that his paternal experience has changed his way of practicing his educational profession, "I look to people, to students in a deeper way and with more dimensions."

He believes that a man is a being able to think, with the necessity of being in contact to build his life that is why he does not agree with the ruling men concept in our society that has stigmatized values. He does not know what an 'educative man' is "but if anyone works in education he must know who he is, what he hopes from life, how we wants to be in contact, etc."

Regarding to future, he believes that the most important for his children is that they feel that their parents love them. He thinks that to be a better father and a better professional is necessary to continue "learning to respect the personal process and taking care of their lives." To complete his children and the students "I think that it is necessary to establish common spaces where we can talk, take advantage of the everyday educational potential, being conscious that they are the protagonists and that they have the answers to their questions."

\section{Conclusions}

The link between paternity as vital experience and the professional educative exercise in the framework of building new ways, more equal, of being a 
de ser padre y educador, nos debe llevar a considerar una serie de categorías, emergentes de nuestras pretensiones, las aproximaciones narrativas desarrolladas y la fundamentación teórica de nuestra investigación. No olvidemos que, en palabras de Imbernón (2002, p. 7): “Investigar, en educación como en cualquier otra disciplina, es necesario para generar cambios, para revisar el conocimiento educativo constituido por la evidencia, la experimentación y la intuición y para generar nuevo conocimiento que permita una mejor educación de los ciudadanos."

En nuestro caso, al relatar y contrastar narraciones de personas que se hallan en situaciones sociales y educativas similares, y al centrar sus testimonios en esas situaciones, hemos intentado sacar provecho de los conocimientos que han adquirido mediante su experiencia directa de ese mundo de la paternidad y su vínculo con su profesión educativa, atendiendo las singularidades, pero sin dejar por ello de lado los elementos comunes que han ido tejiéndose, permitiéndonos esto construir una representación de los componentes sociales y educativos de la situación (Bertaux, 2005). Por eso, es necesario conjugar para el análisis y las conclusiones el atender las singularidades de cada recorrido biográfico sin dejar de lado los espacios emergentes significativos entre los mismos.

De esta manera, entendemos que los expuestos no son razonamientos universalizables sobre masculinidades y educación, sino los puntos de vista de 24 hombres (aunque centrados en este artículo en el desarrollo de los 4 relatos seleccionados) que nos abren a la reflexión sobre aspectos que merece la pena explorar en torno a la experiencia de la paternidad y el ejercicio profesional con hombres dedicados de manera comprometida con la crianza y con la educación.

Desde estas premisas, consideramos que los relatos han dado respuestas sustantivas a los objetivos que nos planteamos con esta investigación. Así, ante la cuestión central de qué ha supuesto la experiencia de la paternidad en sus vidas y en cuanto a su profesión educativa, los colaboradores destacan que el hecho de la paternidad ha supuesto un cambio sustantivo. Hablan de un antes y un después ( $\mathrm{C}_{7}$ y $\mathrm{C}_{4}$ ), o de un cambio radical (C2). La orientación de ese cambio tiene que ver, por un lado, con un cambio de perspectiva personal y, por otro, con los cambios que se producen en relación a lo profesional. father and an educator, may address us to consider a series of categories that emerged from our ambitions, the narrative approaches developed and the theoretical base of our research. We must not forget that, in Imbernon's words (2002, p. 7): "Researching, in education as in any other discipline, is necessary to create changes, to examine the educative knowledge built by the evidence, experimentation and the intuition and to generate a new knowledge that allow a better education of the citizens."

In our case, telling and matching the stories of people that are in similar social and educative situations, and focusing their testimonies in these contexts, we have tried to make the most of the knowledge that they have got through their direct experience to the paternity world and their link with their educational profession, paying attention to the singularities but not for that leaving out the common elements that have grown up, letting these making a presentation of the social and educative components of the situation (Bertaux, 2005.) That is why it is necessary to pay attention to the singularities of each biographic round to analyze and make conclusions without leaving out the emergent meaningful spaces between them.

In this way, we understand that what we have shown are not universalized reasoning about the masculinities and education, but the points of view of 24 men (besides focused in this article in the development of the 4 stories selected) that makes us thinking about the aspects that worth explore around the paternity experience and the professional exercise with men deeply dedicated to raising and education.

From these premises, we consider that the stories have answered to the objectives that we laid out in this research. To the central question about what the paternity experience have meant in their lives and about the educational profession, the contributors highlight that paternity has been a substantive change. They talk about a before and an after ( $\mathrm{C}_{7}$ and $\left.\mathrm{C}_{4}\right)$ or about a radical change (C2.) The direction of this change is related to, on the one hand, a change in the personal perspective, and on the other hand, with the changes that happen relating to professional.

[ 88 ] EDUARDO SALVADOR VILA MERINO, J. EDUARDO SIERRA NIETO Y VÍCTOR M. MARTíN SOlBES SIPS - PEDAGOGIA SOCIAL. REVISTA INTERUNIVERSITARIA [1139-1723 (2014) 23, 71-94] TERCERA ÉPOCA 
En cuanto a los cambios en un plano personal, podemos decir que todos ellos se sienten en el mundo más responsabilizados en relación a sus hijas e hijos. $\mathrm{C}_{1}$ expresa como el profundo amor que siente por su hijo le ha ido llevando a vivir su vida a través de la responsabilidad que adquiere hacia él; $y$ así habla de cuidar de una persona indefensa y educarla para que sea autónoma. En un sentido similar, C2 sostiene que convertirse en padre está relacionado con un cambio en sus preocupaciones, esto es, relativizar según qué preocupaciones y pasar de preocuparse en exclusiva por sí mismo y por su pareja, a hacerlo también (y en primer lugar) por su hija. Para $\mathrm{C}_{4}$, la paternidad está suponiendo cambios a muchos niveles: en las relaciones con amigos, pareja, familia, responsabilidades, etc. Y su deseo de ejercer una paternidad más consciente en ocasiones se encuentra con la difícil conciliación laboral y familiar.

Respecto a los cambios en un plano profesional, los 24 rescatan las implicaciones que la paternidad ha tenido para su labor educativa, y lo traducen de diversas maneras, siendo las de los 4 seleccionados bastante representativas del resto: sentir compromiso y sensibilidad hacia la gente joven $(\mathrm{C}\urcorner)$; una especial sensibilidad hacia la experiencia de ser hijo o hija, y ser padre o madre $\left(\mathrm{C}_{2}\right)$ un acentuado instinto tutorial, que asociamos a un sentido de especial responsabilidad hacia los otros (C3); un respeto profundo hacia los procesos personales y el propio cuidado de la vida (C4).

Todos los colaboradores se muestran conscientes de que, en efecto, las transformaciones que el proyecto de la paternidad y su vivencia va teniendo, se ramifica en muchas facetas de sus vidas. No es sólo el hecho de convertirse en padres, sino el conjunto de transformaciones emocionales, relaciones y simbólicas que se activa y que se pone en juego. En sus narraciones dan muestras de una especial consciencia respecto a dichas transformaciones; y van trazando vínculos entre las distintas esferas de su día a día.

C1 narra cómo el nacimiento de su hijo, acompañado del síndrome de Down, le ha enseñado en primera persona que todos somos diversos $y$ merecemos ser educados en la diversidad. Vemos que no se trata únicamente de un posicionamiento declarativo, sino que es a través de experimentar la diversidad que este hombre ha desarrollado un sentido educativo de la diferencia con mayor calado; y
Regarding to the changes in the personal area, we can say that all of them feel more responsible regarding to their daughters and sons. $\mathrm{C}$ explains how the deep love that he feels for his son have made him to live his life through the responsibility to him; and so he talks about taking care of a defenseless person and educate that person to be self-sufficient. In a similar way, $C_{2}$ says that being a father is related with a change in his concerns, this is, relativizing depending on which concerns and stop worrying just about himself and his couple to start also worrying (and in first place) about his daughter. To $\mathrm{C}_{4}$, paternity is making changes in different levels: in the relationship with his friends, couple, family, responsibilities, etc. And his wish of acting as father it is sometimes faced with the difficult labor and familiar conciliation.

Regarding to the changes in the professional area, the 24 of them tell about the implications that paternity had in their educative task, and they translate it in several ways, being the ones of the 4 selected more representative than the others: feeling compromise and sensitivity to the young people $\left(\mathrm{C}_{1}\right)$; an special sensitivity to the experience of being a son or a daughter, and being a father or a mother $\left(\mathrm{C}_{2}\right)$ a marked tutorial instinct that we relate to an special sense of responsibility to the others ( $C_{3}$ ); a deep respect to the personal processes and life care (C4.)

All the contributors are conscious of the transformations that the paternity project and their experience are making is shown in a lot of their lives' aspects. It is not just the fact of being fathers, it is the total of emotional transformations, relations and symbolic that are activated and brought into play. In their narratives they show an special conscious regarding to those transformations; and they create links between the different areas in their daily life.

$C_{1}$ says how the birth of his son, accompanied by Down syndrome, has taught him in first person that we are all diverse and we deserve to be educated in diversity. We see that is not just about a declarative position, it is through experimenting in diversity how this man has developed a more educative sense about the difference; he makes a passage between that experience and his profession labor. Taking care and growing his child, as 
hace un pasaje entre esa vivencia y su ocupación profesional. Cuidar y criar a su hijo, como decimos, es una fuente de aprendizajes relacionales. $\mathrm{C}_{1}$ afirma que a través de la relación con su hijo ha aprendido el sentido de la paciencia, los ritmos de aprendizaje, la necesidad de reconocer las peculiaridades, las individualidades, evitando la estigmatización y el etiquetaje. Hacer pasar por uno estos aprendizajes, fruto de la relación afectiva con nuestros propios hijos, supone avanzar en la construcción de nuevos marcos pedagógicos sostenidos por la honestidad de las emociones de las que nace.

Para $C_{2}$, que trabaja con niños y niñas con autismo, está resultando especialmente significativo experimentar en primera persona la paternidad de cara a considerar los sentimientos y emociones que las familias y las criaturas con las que trabajan pueden estar experimentando. Esa "apertura" hacia los sentimientos ajenos juega un papel muy relevante en sus concepciones y prácticas educativas: "he adquirido un sentimiento que me hace entender lo que siente un padre, una madre, un hijo, una hija, procuro estar más atento a este sentimiento".

Para C3, reconocer sus emociones y expresar que se define como alguien con mucha sensibilidad, está íntimamente ligado a cómo se considera como educador. Dice no poder separar su yo personal de su yo profesional. $Y$ esa forma de habitar su profesión se vehicula a través de las relaciones educativas que busca sean genuinas, coherentes y transparentes.

$\mathrm{C}_{4}$ sostiene que la experiencia de la paternidad ha cambiado su manera de ejercer la profesión educativa; y así habla de una sensibilidad pedagógica que se concreta en una mirada más honda en relación a los otros. Igualmente traza paralelismos entre el acompañamiento educativo con sus hijos y sus educandos: creo necesario establecer espacios en común donde dialogar, aprovechar el potencial educativo del día a día, ser conscientes de que los protagonistas son ellos y que las respuestas a sus preguntas las tienen ellos".

Por otro lado, reconocer las luces y las sombras de la relación con el propio padre no es una tarea sencilla. Algunos colaboradores lo han obviado en su relato $\left(\mathrm{C}_{1}\right)$ y otros lo han tomando como algo más central ( $C_{2}$ y $\left.C_{4}\right)$. $C_{2}$ narra algunas tensiones vividas en la relación con su padre, pero se esfuerza en rescatar aquello que hay en él que merece la pena we say, is a source of relational learning. C1 claims that through the relation with his child he has learnt the sense of patience, the learning's rhythms, the necessity of recognizing the peculiarities, individualities, avoiding stigmatization and labeling. Going through one of these kinds of learning, result of the affective relation with our own children, means moving forward in the building of new pedagogical frameworks hold by the honesty of the emotions from where it starts.

To C2, who works with autistic boys and girls, it is being especially meaningful to experience in first person the paternity considering the feelings and emotions that the families and children that he works with can experience. That "opening" to someone else's feelings plays an important role in his conceptions and educative practices: "I got a feeling that makes me understand what a father, a mother, a son, a daughter feels, I try to be more attentive to this feeling."

To 3, recognizing his emotions and expressing that he defines himself as someone with a lot of sensitivity is intimately linked to how he considers himself as an educator. He says that he do not separate his personal me from his professional me. And that way of feeling his profession is linked through the educative relations that he look for them to be genuine, coherent and transparent.

C4 claims that the paternity experience has changed his way of being an educator; and so, he talks about a pedagogical sensitivity which is settled on a deeper look to other people. He also makes similarities between the educative accompaniment with his children and his students: "I think that it is necessary to establish common spaces where we can talk, take advantage of the everyday educational potential, being conscious that they are the protagonists and that they have the answers to their questions."

On the other hand, recognizing the lights and shadows of the relationship with their father is not an easy task. Some contributors have avoided it in their story $\left(\mathrm{C}_{1}\right)$ and others have taken it as something more central ( $\mathrm{C}_{2}$ and $\left.\mathrm{C}_{4}\right) . \mathrm{C}_{2}$ tells some tensions lived in the relationship with his father but he makes an effort to rescue the things that are worth to highlight; even that things that he identifies in his father and that he tries to be part

[ 90 ] EDUARDO SALVADOR VILA MERINO, J. EDUARDO SIERRA NIETO Y VÍCTOR M. MARTíN SOLBES SIPS - PEDAGOGIA SOCIAL. REVISTA INTERUNIVERSITARIA [1139-1723 (2014) 23, 71-94] TERCERA ÉPOCA 
reseñar; incluso, aquello que identifica en su padre y trata que forma parte de sí. Y así habla de la importancia de tratar de ser felices, sentirse seguro de sí mismo e intentar buscar el lugar adecuado en la sociedad. Esto no significa que en las tareas de crianza adopte estilos propios de su padre; más bien tiene que ver con un plano personal e identitario. Mientras, $\mathrm{C}_{4}$ sí que se detiene en la narración en aquello que tiene que ver con su padre. Está muy presente en quién es él, y guarda recuerdos de su padre que salen a la luz cuando reflexiona acerca de sus posicionamientos ante la vida. De él aprendió que "el ser humano tiene que ser digno y esforzarse por lo que quiere, y esto no va reñido con el disfrute de las pequeñas cosas".

Asimismo, las concepciones sobre lo masculino y lo femenino están presentes en la guía de escritura que les facilitamos; ahí les insistíamos en que se trata de diferencias culturales y aprendidas en el seno de relaciones sociales. Las posturas de los 4 son muy similares. No creen que existan diferencias sustanciales entre los hombres y las mujeres que se dedican a la educación. $C_{2}$ sostiene que la especial sensibilidad que han de tener quienes se dedican a la educación, es propia tanto de mujeres como de hombres. La sensibilidad y la autoridad son, según él, cualidades totalmente compatibles con la experiencia de los hombres. En un sentido parecido, se pronuncia $\mathrm{C}_{4}$ al decir que las diferencias que pueda haber entre unos y otras, si las hay, "es porque cada uno es diferente, no por cuestiones de género". Para él, lo maternal va unido a "valores de cercanía, afecto, seguridad, cariño, por lo que no creo que lo maternal sea exclusivo de la mujer".

Para C3, al repasar su relato, podemos entender cómo ha ido gestándose en él un profundo sentido de justicia que, en buena medida, cuestiona el orden patriarcal y las ramificaciones que este sistema ideológico tiene en la crianza y la educación de las chicas y de los chicos. Para él está muy claro que buena parte de las dificultades en la convivencia en los centros escolares (donde trabaja) guarda relación con las relaciones de dominio-sumisión estereotipadamente masculinas. Cree que un hombre es un ser dotado de capacidad de pensar, con necesidad de relacionarse para construir su vida, por lo que discrepa del concepto de hombre imperante en nuestra sociedad, que lleva consigo algunos va- of him. And so he talks of the importance of trying to be happy, feeling self-confident and trying to look for the place in society. This does not mean that in the raising tasks he uses the same ways as his father; is related to the personal and identity field. On the other hand, C4 talks more about what is related to his father. He is very sure on who he is and he keeps memories from his father that come out when we reflections about his positioning of life. From him he learned that "the human being has to be worthy and make an effort to obtain what he wants, this does not go against enjoying the little things."

As well, the conceptions about the masculine and the feminine are present in the writing guides that we gave to them; there we insisted that it is about cultural differences learned in the field of the social relationships. The attitudes of the 4 are very similar. They do not believe that there are substantial differences between men and women who are dedicated to education. C2 claims that the especial sensitivity that the ones who work in education must have is present both in women and men. Sensitivity and authority are, for him, features completely compatible with the experience of men. In a similar way talks $\mathrm{C}_{4}$, telling that the differences between ones and others if they exist "is because each one is different, not due to gender matters."

To C3, going over his story, we can understand how the deep sense of justice has grown up in him, in good part it questions the patriarchal order and the division that this ideological system has and the girls and boys education. To him is very clear that a good part of the difficulties in cohabitation in the school (where he works) is related with the stereotyped masculine control-submission relations.

$\mathrm{C}_{4}$ believes that a man is a being able to think, with the necessity of being in contact to build his life, that is why he does not agree with the ruling men concept in our society that has stigmatized values. He does not know what an 'educative man' is, "but if anyone works in education he must know who he is, what he hopes from life, how we wants to be in contact, etc."

In conclusion, we think, as Bolivar, Domingo and Fernandez (1998, p. 152) agree that the use of the 
lores estigmatizadores. No sabe qué es un 'hombre educador', "pero si alguien se dedica a la educación, debe tener claro quién es, lo que espera de la vida, cómo quiere relacionarse, etc.".

En definitiva, pensamos, como plantean Bolívar, Domingo y Fernández (1998, p. 152), que la utilización de la autobiografía constituye una potente herramienta para el desarrollo profesional. Esta investigación ha sido un primer paso en esta dirección, centrada fundamentalmente en abrir nuevas vías de comprensión sobre la experiencia masculina (Seidler, 2006). En este sentido, nuestra propuesta para líneas futuras va en el sentido de desarrollar investigaciones colaborativas, bien a través de grupos de discusión o de otra clase de propuestas, que apoyen el desarrollo profesional, como una línea propia de formación en género orientada hacia los hombres educadores, dada la reconocida falta de modelos masculinos alternativos. Consideramos que existe una necesidad latente en muchos hombres de disponer de espacios donde expresarse en primera persona y compartir junto a otros hombres los entresijos de sus experiencias y las tensiones que acompañan sus actuaciones educativas desde la óptica de la identidad de género. Sobre esta base, cabe plantearse como propósito formativo diseñar y desarrollar espacios de autoconocimiento donde los hombres educadores puedan ir dando forma a sus experiencias desde la reflexión compartida.

Desde esta perspectiva, no debemos olvidar que, dentro de los movimientos sociales disponemos de valiosos referentes que llevan largo tiempo proponiendo esta clase de espacios, y cuya experiencia puede resultar valiosa para la formación y el desarrollo profesional de educadores. Asimismo, hacemos énfasis en la promoción e incentivación de más investigaciones que se interesen por el estudio de las masculinidades en profesionales de la educación, ante la constatación de los escasos estudios de los que disponemos. Pensemos que la literatura sobre coeducación lleva tiempo insistiendo en la necesidad de que los chicos (también las chicas) dispongan de nuevos referentes adultos masculinos en general, y parentales en particular. En este sentido, necesitamos trabajar parar favorecer esos otros referentes a través de actuaciones educativas y de acompañamiento. autobiography is an useful tool to the professional development. This research has been the first step in that direction, essentially focused in opening new understanding routes about the masculine experience (Seidler, 2006.) In this way, our proposal to future lines is to develop collaborative researches, through discussion groups or another kind of proposals that support the professional development as a typical line of gender training address to educative men, due to the lack of alternative masculine models. We consider that there exists a necessity in a lot of men to have spaces where they can express themselves in first person and sharing with other men their experiences and the tensions in their educative actions from the side of gender identity. On this basis, we must contemplate as formative purpose to design and develop self-awareness spaces where educative men can shape their experiences from the shared reflection.

From this perspective, we must not forget that, within the social movements we have valuable referents that have been proposing for a while this kind of spaces, and its experience can be valuable to the training and professional development of the educators. As well, we highlight the promotion and motivation of more researchers that are interested in the study of the masculinities in educative professionals, facing the verification of the limited studies that we have. We must think that the literature about coeducation has been insisting for a lot of time on the necessity for the boys (and girls) to have new masculine adults' referents in general and parental in particular. In this sense, we have to work to promote those other referents trough educative and accompaniment actions.

[ 92 ] EDUARDO SALVADOR VILA MERINO, J. EDUARDO SIERRA NIETO Y VÍCTOR M. MARTíN SOLBES SIPS - PEDAGOGIA SOCIAL. REVISTA INTERUNIVERSITARIA [1139-1723 (2014) 23, 71-94] TERCERA ÉPOCA 


\section{Bibliografía / References}

Bertaux, D. (2005). Los relatos de vida. Barcelona: Bellaterra.

Blanco, N. \& Sierra, J. E. (2013). La experiencia como eje de la formación: una propuesta de formación inicial de educadoras y educadores sociales. Archivos Analíticos de Políticas Educativas. IN PRESS

Bolívar, A.; Domingo, J. \& Fernández, M. (1998). La investigación biográfico-narrativa en educación. Guía para indagar en el campo. Granada: FORCE.

Bolívar, A.; Domingo, J. \& Fernández, M. (2001). La investigación biográfico-narrativa en educación: enfoque y metodología. Madrid: La Muralla.

Bonino, L. (2003). Las nuevas paternidades. Cuadernos de Trabajo Social, 16, pp. 171-182.

Bourdieu, P. (2000). La dominación masculina. Barcelona: Anagrama.

Carrera, M. V. (2013). Educando Queer: el educador/a social como agente de subversión de género en la escuela. Revista Iberoamericana de Educación, 61/2.

Connell, R. W. (1987). Gender and power. Sidney: Allen and Unwin.

Connell, R. W. (1997). Enseñar a los chicos. Nuevas investigaciones sobre la masculinidad y estrategias de género para la escuela. Kikiriki, 46, pp. 51-68.

Contreras, J. (1991). El sentido educativo de la investigación. Cuadernos de Pedagogía, 196, pp. 61-67.

Cortés, P.; Caparrós, E. \& Sierra, J. E. (2013). "Tejiendo" un saber de la experiencia sobre las relaciones educativas. Una mirada desde los contextos de acogida y reforma juvenil. Sinergias, 1-2, pp. 57-70.

CREA (2011). Impacto de los actos comunicativos en la construcción de nuevas masculinidades. Plan Nacional I+D+i, 2010-11. Ministerio de Ciencia e Innovación.

Esbrina (2007). ¿Cómo se aprende a ser chico? Una investigación sobre el aprendizaje de la masculinidad entre los adolescentes. CIDE-MEC e Instituto de la Mujer. Ministerio de Trabajo y Asuntos Sociales. 2005-2007.

Guash, O. (Coord.) (2012). Vidas de hombres. Barcelona: Bellaterra.

Imbernón, F. (2002). La investigación educativa como herramienta de formación del profesorado. Barcelona: Graó.

Kimmel. M. (2000). The Gendered society. New York : Oxford University Press.

Lomas, C. (2004). Los chicos también lloran. Barcelona: Paidós.

Mac an Ghaill, M. (1994). The Making of Men: Masculinities, Sexualities and Schooling. Buckingham: Open University Press.

Martino, W. \& Pallotta-Chiarotti, M. (2006). Pero, ¿qué es un chico? Aproximación a la masculinidad en contextos escolares. Barcelona: Octaedro.

Novara, D. (2003). Pedagogía del saber escuchar. Madrid: Narcea.

Oliver, E. \& Valls, R. (2004). Violencia de género. Investigaciones sobre quiénes, por qué y cómo superarla. Barcelona: El Roure.

Rivas, I. (2009). Narración, conocimiento y realidad. Un cambio de argumento en la investigación educativa. In I. Rivas Flores \& D. Herrera Pastor. Voz y educación. La narrativa como enfoque de interpretación de la realidad, (pp. 17-36.) Barcelona: Octaedro.

Sancho, J. M.; Hernández, F.; Herraiz, F.; \& Vidiella, J. (2009). Una investigación narrativa en torno al aprendizaje de las masculinidades en la escuela. Revista Mexicana de Investigación Educativa, 14 - 43, pp. 1.155-1.189.

Seidler, V. (2000). La sin-razón masculina. México: Paidós.

Seidler, V. (2006). Masculinidades. Culturas globales y vidas íntimas. España: Montesinos.

\section{CÓMO CITAR ESTE ARTÍCULO / HOW TO CITE THIS ARTICLE}

Vila Merino, E. S., Sierra Nieto, J. E. y Martín Solbes, V. M. (2014). Estudio narrativo sobre la experiencia de la paternidad en profesionales de la educación. Pedagogía Social. Revista Interuniversitaria, 23, 71-94. DOI: 10.7179/PSRI_2014.23.04

Vila Merino, E. S., Sierra Nieto, J. E. \& Martín Solbes, V. M. (2014). Narrative study on the experience of paternity in education professionals. Pedagogia Social. Revista Interuniversitaria, 23, 71-94. DOI: 10.7179/PSRI_2014.23.04

Fecha de recepción del artículo / received date: 25.111.2013

Fecha de revisión del artículo / reviewed date: 21.VI.2013

Fecha de aceptación final / accepted date: 31.VII.2013 


\section{DIRECCIÓN DEL AUTOR/ AUTHOR' ADDRESSES}

Eduardo S. Vila Merino y Víctor M. Martín Solbes. Departamento de Teoría e Historia de la Educación. Facultad de Ciencias de la Educación. Universidad de Málaga. eduardo@uma.es, victorsolbes@uma.es

J. Eduardo Sierra Nieto. Departamento de Didáctica y Organización Escolar. Facultad de Ciencias de la Educación. Universidad de Málaga. esierra@uma.es

\section{PERFIL ACADÉMICO / ACADEMIC PROFILE}

Eduardo Salvador Vila Merino. Profesor Contratado Doctor. Departamento de Teoría e Historia de la Educación de la UMA. Ha trabajado en el ámbito de la educación social y como maestro de primaria y de interculturalidad. También ha sido Coordinador de Programas Europeos e Interculturalidad en la Delegación Provincial de Educación de Málaga. Miembro del Grupo de Investigación HUM-169 “Teoría de la Educación y Pedagogía Social". Ha participado en distintos proyectos de investigación e innovación educativa a nivel local, estatal e internacional. Líneas de investigación principales: educación intercultural, derechos humanos y cultura de paz, pedagogía social, políticas educativas, teoría de la educación, igualdad de género. Estancias de formación e investigación en distintas universidades latinoamericanas. Autor o coordinador de 12 libros y 30 capítulos de libro, además de más de 40 artículos en revistas.

J. Eduardo Sierra Nieto. Doctor en Pedagogía por la Universidad de Málaga. Tras tres años trabajando como educador social con menores en protección, se incorporó al Departamento de Didáctica y Organización Escolar de la citada universidad como investigador predoctoral en formación (2009-2013). Durante ese tiempo ha estado colaborando en diferentes investigaciones dentro del grupo al que pertenece (Innovación y evaluación educativa andaluza), relacionadas con la evaluación educativa de los aprendizajes, la vivencia fenomenológica de la escuela y la pedagogía de la diferencia sexual. También ha desempeñado tareas docentes relacionadas con el diseño de programas, y ha sido investigador visitante en universidades nacionales (Almería) y extranjeras (Verona, Italia).

Víctor M. Martín Solbres. Doctor en Pedagogía por la Universidad de Málaga. Ha sido educador social en el Centro Penitenciario de esta ciudad y actualmente es Profesor en el Departamento de Teoría e Historia de la Educación de la Facultad de Ciencias de la Educación de la Universidad de Málaga, donde desarrolla su tarea docente e investigadora, que gira alrededor del mundo penitenciario, las drogodependencias, la exclusión social, la interculturalidad, cuestiones de género, investigación sobre la paz y la gestión de conflictos. Estas investigaciones se desarrollan desde perspectivas pedagógicas y desde la educación social, originando diversas publicaciones, contribuciones a congresos y conferencias. Coordinador, en la Universidad de Málaga, del Máster Interuniversitario sobre Cultura de Paz, Conflictos, Educación y Derechos Humanos.

[ 94 ] edUARDo SALVADOR VILA MERINO, J. EDUARDO SIERRA NIETO Y Víctor M. MARTín SOlbeS

SIPS - PEDAGOGIA SOCIAL. REVISTA INTERUNIVERSITARIA [1139-1723 (2014) 23, 71-94] TERCERA ÉPOCA 